\title{
Physical activity among medical students of university sultan zainal abidin (UniSZA), Malaysia
}

\author{
Charan Kishor Shetty ${ }^{*}$, Myat Moe Thwe Aung ${ }^{2}$, San San OO $^{3}$, Nordin Simbak ${ }^{4}$ \\ ${ }^{1,2}$ Assistant Professor, ${ }^{3}$ Associate Profesor, ${ }^{4}$ Professor, ${ }^{1}$ Dept. of Forensic Medicine, Faculty of Medicine, ${ }^{\mathbf{2}, \mathbf{3}}$ Dept. of Community Medicine, \\ ${ }^{4}$ Dept. of Orthopaedics, ${ }^{1-4}$ University Sultan Zainal Abidin, Terengganu, Malaysia
}

\begin{abstract}
Introduction: Physical activity is considered as one of the best way by which we can keep our body active and disease free. Medical college students have to cope up with the stress and demands of the medical education. Therefore, this study was undertaken to assess the physical activities during the last 7 days among the medical students in UniSZA.

Objectives: To describe the physical activities during the last 7 days among the medical students of UniSZA and compare them according to gender and different study years.

Materials and Methods: A cross-sectional study was carried out among all medical students (from Year 1 to Year 5) of UniSZA.

Results: Of the 310 successfully distributed, a total of 238 completed questionnaires were received, indicating a response rate of $76.8 \%$. From a total of 238 respondents, 69(29.0\%) were males and 169(71.0\%) were females. The ratio for gender male to female of medical students of UniSZA is 3:7. From the data, Year 1 respondents were 44 students $(18.5 \%)$ out of 60 students, Year 2 were 52 students $(21.8 \%)$ out of 64 students, Year 3 were 46 students (19.3\%) out of 60 students, Year 4 were 40 students (16.8\%) out of 62 students and 56 students $(23.5 \%)$ out of 65 students for Year 5. For the past seven days, 109 students $(45.8 \%)$ did vigorous activity. More than half of the students (59.2\%) did moderate activity and 97 students (40.8\%) did not. Meanwhile, for walking at least 10 minutes per day, 224 walked and 14 did not. As for sitting, 182 respondents chose Yes and 55 respondents chose No.

Conclusion: Implication of this study suggest that within this population, in the time diary provided (last 7 days) satisfied the recommendation on physical activity by WHO. There is a need to provide an enabling environment for promoting the physical activity amongst them so that can inculcate the same in their patients.
\end{abstract}

Keywords: Physical activities, Walking, Running, Moderate, Vigorous.

\section{Introduction}

It is known fact that a decrease in the physical activity is associated with various chronic diseases. ${ }^{1}$ Physical activity is defined as any bodily movement produced by skeletal muscles that require energy expenditure. Physical inactivity has been identified as the fourth leading risk factor for global mortality causing an estimated 3.2 million deaths globally according to World Health Organisation(WHO). ${ }^{1}$ Physical activity has been classified in three categories vigorous physical activity, moderate intensity and low intensity. ${ }^{2}$ The American Heart Association together with WHO and the American College of Sport Medicine (ACSM) unanimously recommend 30 minutes of moderateintensity physical activity 5 days per week or 20 minutes of vigorous-intensity physical activity 3 days per week for all adults. ${ }^{3}$ The WHO highlights that every activity that lasts more than 10 minutes is beneficial. ${ }^{2}$

Malaysia is in the midst of obesity epidemic, with almost half the county overweight or obese. New figures show that almost $18 \%$ of the country, or more than five million people, can be classed as obese. A further $30 \%$ are overweight. Twenty years ago, only $4.4 \%$ of Malaysians were considered obese. A decade later that had jumped to $14 \% .^{3}$
University students typically have a busy schedule with their academic, extracurricular activities, work and social lives, which is a primary contributing factor relating to the decline of physical activity, and additionally creates great stress for meeting high academic standards, which in turn can create various psychological complications. ${ }^{4}$ Epidemiological evidence indicates that the level of physical activity declines from high school to college, and activity patterns in college populations are generally insufficient to improve health and fitness. To be specific, only $38 \%$ of college students participate in regular vigorous activity and only $20 \%$ participate in regular moderate activity. ${ }^{5}$

Prior studies have shown that $60 \%$ of college students do not on average accumulate the recommended amount of physical activity for an adult and are unaware that adults should exercise five days a week for 30 minutes at moderate intensities in order to achieve maximum health benefits. ${ }^{6}$

Physical inactivity tends to increase during aging process with the most dramatic increase occurring in late adolescence and early adulthood. Recently, university students have demonstrated the propensity for being physically inactive. ${ }^{7}$ One study of vigorous physical activity (VPA) found $56 \%$ of college freshmen who had been vigorously active during their senior year of high school

\footnotetext{
*Corresponding Author: Charan Kishor Shetty, Dept. of Forensic Medicine, Faculty of Medicine, University Sultan Zainal Abidin, Terengganu, Malaysia

Email: charanshetty768@gmail.com

http://doi.org/10.18231/J.IJFCM.2019.029
} 
were no longer engaging in vigorous amounts of physical activity. ${ }^{8-10}$ Overall, vigorous activity tends to decline from adolescence to adulthood. ${ }^{10-13}$

With this background in mind, the current study was designed to assess the physical activities during the last 7 days among the medical students in UniSZA.

\section{Materials and Methods}

\section{Study design and study participants}

A cross-sectional study was carried out among all medical students (from Year 1 to Year 5) of UniSZA.

\section{Study instruments}

Each student was interviewed by using the validated International Physical Activity Questionnaires (IPAQ) comprising a set of 7 items. Verbal consents will be taken from all respondents prior to the interview. All interviewees will be explained in details about full description of the research, confidentiality and voluntary participation. Those who do not to want to participate in the study will be excluded in this study.

\section{Data Analysis and statistical application}

Data entry and analysis was done using SPSS version 22. Descriptive statistics was applied such as frequency (\%) for categorical data and mean (SD) for numerical data.

\section{Limitations}

The number of respondents were relatively small. The main study limitations included its cross-sectional nature and the possibility of self-report biases. Further research is warranted to expand the study nationally and determine which factors influence physical activity.

\section{Results}

Of the 310 successfully distributed, a total of 238 completed questionnaires were received, indicating a response rate of $76.8 \%$. From a total of 238 respondents, 69(29.0\%) were males and $169(71.0 \%)$ were females. The ratio for gender male to female of medical students of UniSZA is 3:7. From the data, Year 1 respondents were 44 students $(18.5 \%)$ out of 60 students, Year 2 were 52 students $(21.8 \%)$ out of 64 students, Year 3 were 46 students $(19.3 \%)$ out of 60 students, Year 4 were 40 students $(16.8 \%)$ out of 62 students and 56 students $(23.5 \%)$ out of 65 students for Year 5 .

For the past seven days, 109 students (45.8\%) did vigorous activity. More than half of the students $(59.2 \%)$ did moderate activity and 97 students (40.8\%) did not. Meanwhile, for walking at least 10 minutes per day, 224 walked and 14 did not. As for sitting, 182 respondents chose Yes and 55 respondents chose No (Table. 1).

Statistical tests used are Independent $\mathrm{T}$ test for gender comparison and One-Way ANOVA for year of study comparison. Parametric test are chosen as the sample size is large (more than 30 participants), although the graph is skewed to the right. Levene's test was performed for Independent $\mathrm{T}$ test to check for variance equality. For OneWay ANOVA, post hoc analysis were made due to significant value for Year 1 and Year 2 (Table 2, 3).

Table 1: Physical activities during the last 7 days among the medical students in UniSZA $(\mathrm{n}=238)$

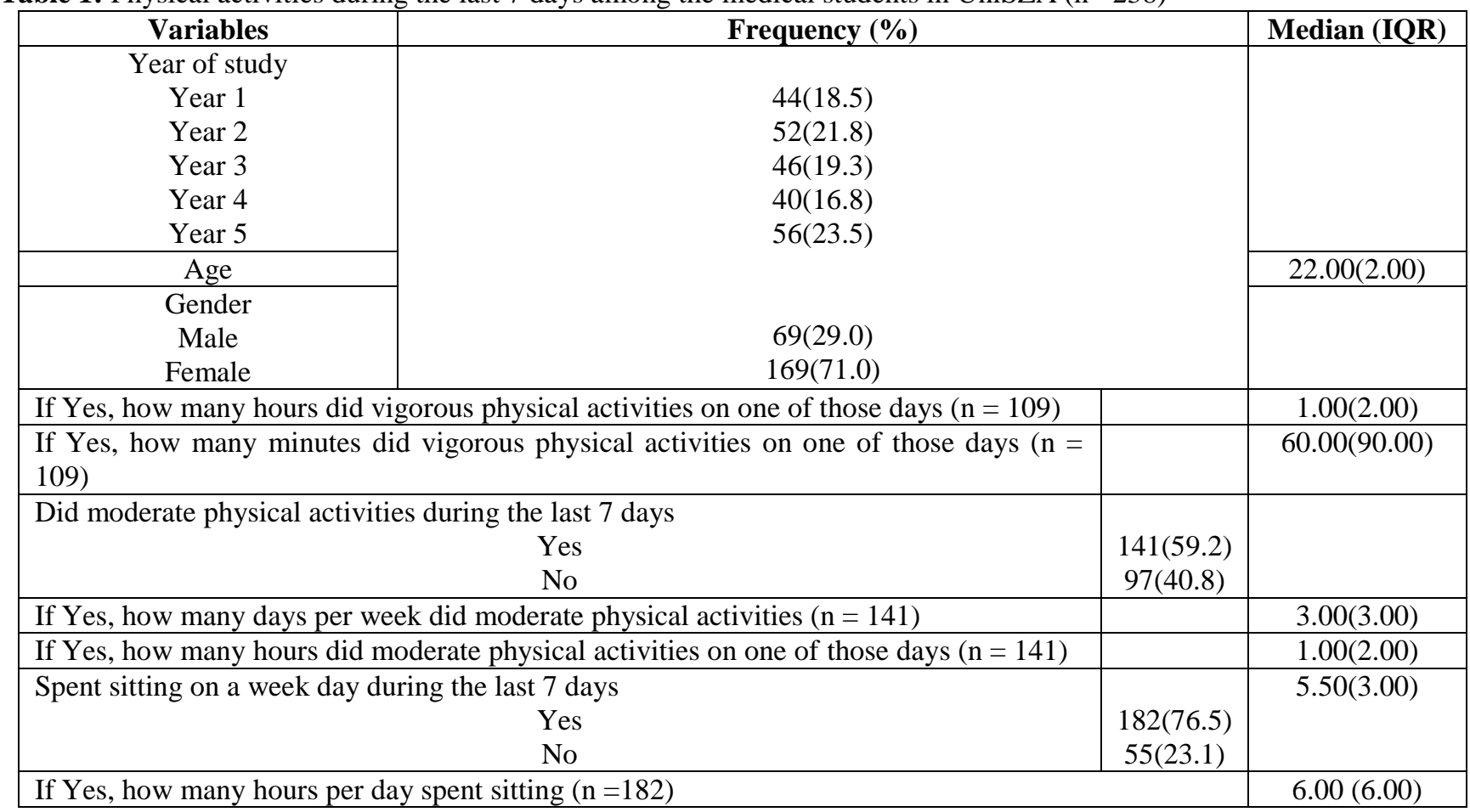




\section{Comparison by gender}

We compared responses of the study by revealing the intensity of physical activity done by male and female. This study shows females are more likely to get involve in physical activity compared to males for the past seven days. However, it is not significant according to Independent $\mathrm{T}$ test values (Table 2).

Table 2: Comparison of the physical activities between male and female medical students in UniSZA $(n=238)$

\begin{tabular}{|c|c|c|c|c|c|}
\hline \multirow[t]{2}{*}{ Variables } & \multicolumn{2}{|c|}{ Mean (SD) } & \multirow{2}{*}{$\begin{array}{l}\text { Mean difference } \\
\quad(95 \% \mathrm{CI})\end{array}$} & \multirow{2}{*}{$\begin{array}{l}t \text { statistics } \\
\text { (df) }\end{array}$} & \multirow[t]{2}{*}{$p$-value* } \\
\hline & Male & Female & & & \\
\hline $\begin{array}{l}\text { How many days per week did vigorous physical } \\
\text { activities }(\mathrm{n}=109)\end{array}$ & $\begin{array}{c}2.72 \\
(1.43)\end{array}$ & $\begin{array}{c}2.64 \\
(1.78)\end{array}$ & $\begin{array}{c}0.08 \\
(-0.58,0.73)\end{array}$ & $\begin{array}{l}0.226 \\
(107)\end{array}$ & 0.822 \\
\hline $\begin{array}{l}\text { How many hours did vigorous physical activities } \\
\text { on one of those days }(n=109)\end{array}$ & $\begin{array}{l}1.20 \\
(0.74)\end{array}$ & $\begin{array}{c}5.53 \\
(19.95)\end{array}$ & $\begin{array}{c}-4.33 \\
(-9.09,0.433)\end{array}$ & $\begin{array}{c}-1.814 \\
(69.335)\end{array}$ & 0.074 \\
\hline $\begin{array}{l}\text { How many minutes did vigorous physical } \\
\text { activities on one of those days }(\mathrm{n}=109)\end{array}$ & $\begin{array}{c}71.78 \\
(44.08)\end{array}$ & $\begin{array}{c}81.29 \\
(68.10)\end{array}$ & $\begin{array}{c}-9.50 \\
(-33.54,14.53)\end{array}$ & $\begin{array}{c}-0.784 \\
(107)\end{array}$ & 0.435 \\
\hline $\begin{array}{l}\text { How many days per week did moderate physical } \\
\text { activities }(n=141)\end{array}$ & $\begin{array}{c}3.36 \\
(2.06)\end{array}$ & $\begin{array}{c}3.01 \\
(1.71)\end{array}$ & $\begin{array}{c}0.35 \\
(-0.35,1.06)\end{array}$ & $\begin{array}{c}0.994 \\
(70.849)\end{array}$ & 0.323 \\
\hline $\begin{array}{l}\text { How many hours did moderate physical activities } \\
\text { on one of those days }(n=141)\end{array}$ & $\begin{array}{c}7.93 \\
(24.93)\end{array}$ & $\begin{array}{c}10.06 \\
(28.61)\end{array}$ & $\begin{array}{c}5.00 \\
(-12.02,7.76)\end{array}$ & $\begin{array}{c}-0.425 \\
(139)\end{array}$ & 0.325 \\
\hline $\begin{array}{l}\text { How many minutes did moderate physical } \\
\text { activities on one of those days }(n=141)\end{array}$ & $\begin{array}{c}77.84 \\
(49.62)\end{array}$ & $\begin{array}{c}61.75 \\
(58.80)\end{array}$ & $\begin{array}{c}10.20 \\
(-4.09,36.25) \\
\end{array}$ & $\begin{array}{l}1.577 \\
(139)\end{array}$ & 0.759 \\
\hline $\begin{array}{l}\text { How many days spent walking for at least } 10 \\
\text { minutes at a time }(\mathrm{n}=222)\end{array}$ & $\begin{array}{c}5.39 \\
(1.95)\end{array}$ & $\begin{array}{c}5.90 \\
(7.64)\end{array}$ & $\begin{array}{c}-0.51 \\
(-2.45,1.43) \\
\end{array}$ & $\begin{array}{c}-0.521 \\
(220)\end{array}$ & 0.603 \\
\hline $\begin{array}{l}\text { How many hours spent walking on one of those } \\
\text { days walking }(n=223)\end{array}$ & $\begin{array}{c}13.72 \\
(33.14)\end{array}$ & $\begin{array}{c}11.98 \\
(31.01)\end{array}$ & $\begin{array}{c}1.74 \\
(-7.57,11.05)\end{array}$ & $\begin{array}{l}0.368 \\
(221)\end{array}$ & 0.713 \\
\hline $\begin{array}{l}\text { How many minutes spent walking on one of those } \\
\text { days }(n=223)\end{array}$ & $\begin{array}{c}69.80 \\
(103.63) \\
\end{array}$ & $\begin{array}{c}66.30 \\
(100.29) \\
\end{array}$ & $\begin{array}{c}3.50 \\
(-26.29,33.29) \\
\end{array}$ & 0.232 & 0.817 \\
\hline How many hours per day spent sitting $(\mathrm{n}=182)$ & $\begin{array}{c}9.75 \\
(13.55)\end{array}$ & $\begin{array}{c}6.96 \\
(4.53) \\
\end{array}$ & $\begin{array}{c}2.79 \\
(-1.06,6.64) \\
\end{array}$ & $\begin{array}{c}1.452 \\
(55.623) \\
\end{array}$ & 0.152 \\
\hline How many minutes per day spent sitting $(\mathrm{n}=182)$ & $\begin{array}{c}472.38 \\
(300.32)\end{array}$ & $\begin{array}{c}417.46 \\
(271.89)\end{array}$ & $\begin{array}{c}54.93 \\
(-35.81,145.66) \\
\end{array}$ & $\begin{array}{l}1.194 \\
(180)\end{array}$ & 0.234 \\
\hline
\end{tabular}

*Independent t-test

\section{Comparison by year of study}

One-Way ANOVA was used to compare the study years. There was a significant value between Year 1 and Year 2 at the $\mathrm{p}<$ 0.05 for the three conditions $[\mathrm{F}(4,104)=2.522, \mathrm{p}=0.045]$. Year $1(\mathrm{M}=3.69, \mathrm{SD}=1.92)$ and Year $2(\mathrm{M}=2.12, \mathrm{SD}=1.92)$ (Table 2)

Table 3: Comparison of the physical activities among medical students with different study years at UniSZA

\begin{tabular}{|c|c|c|c|c|c|c|c|}
\hline \multirow{2}{*}{ Variables } & \multicolumn{5}{|c|}{ Frequency (\%) } & \multirow[t]{2}{*}{$X^{2}(\mathrm{df})$} & \multirow{2}{*}{$\begin{array}{c}P \\
\text { value* }\end{array}$} \\
\hline & Year 1 & Year 2 & Year 3 & Year 4 & Year 5 & & \\
\hline $\begin{array}{l}\text { Did vigorous physical activities during } \\
\text { the last } 7 \text { days }\end{array}$ & $16(14.7)$ & $25(22.9)$ & $23(21.1)$ & $19(17.4)$ & $26(23.9)$ & $3.248(4)$ & 0.517 \\
\hline $\begin{array}{l}\text { Did moderate physical activities } \\
\text { during the last } 7 \text { days }\end{array}$ & $30(21.3)$ & $33(23.4)$ & $30(21.3)$ & $19(13.5)$ & $29(20.6)$ & $4.071(4)$ & 0.396 \\
\hline $\begin{array}{l}\text { Walked for at least } 10 \text { minutes at a } \\
\text { time during the last } 7 \text { days }\end{array}$ & $43(19.2)$ & $52(23.2)$ & $42(18.8)$ & $36(16.1)$ & $51(22.8)$ & $3.991(4)$ & 0.407 \\
\hline $\begin{array}{l}\text { Spent sitting on a week day during the } \\
\text { last } 7 \text { days }\end{array}$ & $32(17.6)$ & $39(21.4)$ & $40(22)$ & $32(17.6)$ & $39(21.4)$ & $1.791(4)$ & 0.774 \\
\hline
\end{tabular}

*Pearson's chi-square goodness-of-fit

\section{Discussion}

From the study, percentage on moderate-intensity physical activity was higher compared to vigorous-intensity physical activity. It might be due to lacking in facilities and services related to vigorous physical activity while moderate physical activity is easier to be done. ${ }^{14}$
The results showed significant differences between physical activities between male and female according to vigorous, moderate, walking and sitting. Regarding the difference in study years, the results showed significant differences only in between Year 1 and Year 2 and no significant difference across other study years. 
Most investigators report higher rates of inactivity in women compared to men, with $10-37 \%$ of the college-aged men and $22-48 \%$ of the college-aged women reporting no physical activity in the past month. ${ }^{7}$ Women were significantly more likely than men to report participation in aerobics and moderate activities such as walking. ${ }^{8}$ Male students were significantly more physically active than their female counterparts when assessed by days per week spent engaged in aerobic exercise and strength training. Male students also reported significantly higher levels of overall screen time and television viewing, whereas female students reported significantly higher levels of time spent engaged in homework. $^{9}$ New findings showed that $49 \%$ of women and $44 \%$ of men in Malaysia were found to be obese. ${ }^{10}$

\section{Comparison between gender}

In vigorous activity, female presented slightly higher in frequency of day and quite significantly greater in time spent per day compared to male. Regardless of the gender, it satisfied the recommendation governed by WHO to spend at least 75 minutes of vigorous-intensity aerobic physical activity throughout the week. ${ }^{15}$

As for moderate activity, male indicated slight higher for regularity of day but female showed higher in time spent per day. Both genders fulfil the recommendation that adults aged 18-64 years should do at least 150 minutes of moderate-intensity aerobic physical activity throughout the week. ${ }^{16}$

No suggestive difference in time spent for walking between genders. It may be due to the same factor which is route distance between their college and campus that students need to go through daily regardless of their gender.

Male suggested greater time spent in sitting compared to female. This result may suggested that because male spent more of their time sitting to play games on leisure time. It corresponded to previous findings which proposed female play fewer games than male because they are required to fulfil more obligatory activities, leaving them less available leisure time, which in turn makes them less likely to "make" time for games. ${ }^{17}$

Overall from all type of physical activities, female students showed more physically active than male. This may relate to previous findings, ${ }^{18}$ that concluded females are more concern about their physical appearance and body weight. ${ }^{19,20}$

\section{Comparison between study years}

From the result, there was significantly difference in vigorous physical activities between Year 1 and Year 2 . Year 1 students did more vigorous physical activities due to less commitment for examination compared to Year 2 that needed to sit for Professional Examination. Thus Year 1 students have more free and leisure time to spend on doing physical activity.

There was no significant difference between Year 3, Year 4 and Year 5 students since these three groups of students are in the clinical phase of study. They shared almost the same pattern of schedule thus no such big differences between each.

\section{Conclusion}

University students are continuously challenged by choosing between all kinds of activities (including physical and sedentary activities). Depending on their time schedule, a certain amount of self-discipline is needed to be physically active and not to engage in convenient sedentary activities.

\section{Source of Funding}

None.

\section{Declaration of Interests}

None.

\section{Conflicts of Interest}

None.

\section{Ethical Approval}

The study protocol was approved by the University Human Research Ethics (UHREC), UniSZA: UniSZA.N/1/TD2/628-1 (31).

\section{References}

1. Physical Activity Basics. (2015, June 04). Retrieved July 03, 2017, from http://www.cdc.gov/physicalactivity/basics/index.htm.

2. Judge L, Bellar D, Lee D, Petersen J, Wanless E, Surber K et al, (2012, November 16). An Exploratory Study of Physical Activity Patterns of College Students at a Midwest State University in the United States $\mid$ Sport J Retrieved July 03, 2016, from http://thesportjournal.org/article/an-exploratorystudy-of-physical-activity-patterns-of-college-students-at-amidwest-state-university-in-the-united-states/

3. Scawen, S. (2016, February 4). Obesity statistics ring alarm bells in Malaysia. Retrieved July 03, 2016, from http://www.aljazeera.com/news/2016/02/obesity-statisticsring-alarm-bells-malaysia-160203131123319.html

4. Judge L, Bellar D, Lee D, Petersen J, Wanless E, Surber K et al, (2012, November 16). An Exploratory Study of Physical Activity Patterns of College Students at a Midwest State University in the United States | The Sport Journal. Retrieved July 03, 2016, from http://thesportjournal.org/article/anexploratory-study-of-physical-activity-patterns-of-collegestudents-at-a-midwest-state-university-in-the-united-states/

5. Kilpatrick M, Hebert E, \& Bartholomew J. College Students' Motivation for Physical Activity: Differentiating Men's and Women's Motives for Sport Participation and Exercise. $J$ Am Coll Health 2005;54(2);87-94.

6. Mcarthur, L. Race and Sex Differences in College Student Physical Activity Correlates. Ajhb Am J Health Behavior 2009;33(1):80-90.

7. Ferrara, C. M. (2009, February 1). Physical Activity, Nutrition, and the College Experience. Retrieved July 4, 2016, from http://www.asep.org/asep/asep/Ferrara12_1_23-35.pdf

8. Pinto BM. A stages of change approach to understanding college students' physical activity. J Am Coll Health 1995;44(1):27-31.

9. Fountaine C, Liguori G, \& Mozumdar A. (2008). Television Viewing, Screen Time, and Physical Activity in College Students. Medicine \& Science in Sports \& Exercise, 40(Supplement). Retrieved August 4, 2016. 
10. T. S. (2014, June 16). Malaysia's obesity rate highest in Asia. Retrieved August 04, 2016, from http://www.thestar.com.my/news/nation/2014/06/16/obesitymalaysia-highest-in-asia-says-pm-science-advisor/

11. Keating, XD, Castelli, D, Castro-Pinero, J, and Guan, H. Universitystudent meeting the recommended standards of physical activityand body mass index. ICHPER-SD J Res 2011;6:20-26.

12. Bray SR, Born HA. Transition to university and vigorous physical activity: Implications for health and psychological well-being. J Amer Coll Health 2004;52:181-8.

13. Nelson TF, Gortmaker SL, Subramanian SV, Wechsler H. Vigorous physical activity among college students in the United States. J Phys Act Health 2007;4(4):495-508.

14. Latif. (2014, November 20). Impact of Sport Complex Services towards Costumer Behaviour in Terengganu. Retrieved August 07, 2016, from

http://www.sciencedirect.com/science/article/pii/S1877042814 055165 .

15. Global recommendations on physical activity for health. (2010). Retrieved August 07, 2016, from http://www.who.int/dietphysicalactivity/factsheet_recommend ations/en/ Winn, J., \& Heeter, C. (2009, June 09).

16. Pliner P, Chaiken S, \& Flett G. L. (1990, June). Gender Differences in Concern with Body Weight and Physical
Appearance Over the Life Span. Retrieved August 07, 2016, from http://psp.sagepub.com/content/16/2/263.short.

17. Salmon J, Tremblay MS, Marshall SJ, Hume C. Health risks, correlates, and interventions to reduce sedentary behavior in young people. Am J Prev Med 2011;41(2):197-206.

18. Uijtdewilligen L, Nauta J, Singh AS, van Mechelen W, Twisk JW, van der Horst K, et al. Determinants of physical activity and sedentary behaviour in young people: a review and quality synthesis of prospective studies. Br J Sport Med 2011;45(11):896-905.

19. Alaranta A, Alaranta H, Holmila J, Palmu P, Pietila K, \& Helenius I et al. Self-reported attitudes of elite athletes towards doping: Differences between type of sport. Int J Sports Med 2006;27,842-846

20. US Depth of Labor, Bureau of Labor Statistics. Am Time Use Sur Available at: http://www.bls.gov/tus/datafiles_2008.htm. Accessed July 3;2017.

How to cite this article: Shetty CK, Aung MMT, San San OO, Simbak N. Physical activity among medical students of university sultan zainal abidin (UniSZA), Malaysia. Indian J Forensic Community Med 2019;6(3):125-9. 